\title{
Cytochalasins A and B from Strains of Phoma exigua var. exigua and Formation of Cytochalasin B in Potato Gangrene
}

\author{
By P. M. SCOTT, J. HARWIG, Y-K. CHEN AND B. P. C. KENNEDY \\ Health Protection Branch, Health and Welfare Canada, \\ Ottawa, Ontario KI $A$ oL2, Canada
}

(Received 7 October 1974)

INTRODUCTION

On the basis of a correlation between the severity of potato late blight (caused by Phytophthora infestans) and incidence of anencephaly and spina bifida in humans, Renwick (1972, 1973) proposed a hypothesis that $95 \%$ of the occurrences of these birth defects could be prevented by avoidance of the potato during early pregnancy. This hypothesis was not restrictive to direct involvement of late blight. Shepard (1973) made the suggestion that cytochalasin B, which has been shown to produce neural tube closure defects in explanted chick embryos (Linville \& Shepard, 1972), might be the teratogenic agent. Cytochalasins A and B, which are compounds possessing unusual activity toward cultured cells (Carter, 1972), are known to be produced by Helminthosporium dematioideum and a Phoma sp. (Aldridge, Armstrong, Speake \& Turner, 1967; Rothweiler \& Tamm, 1970). It therefore appeared desirable to examine strains of potato pathogens belonging to the same genera, in particular Helminthosporium atrovirens ( $\mathrm{H}$. solani) and Phoma exigua, for cytochalasins A and B and related compounds. Helminthosporium atrovirens causes 'silver scurf' (Conners, 1967) while two varieties of $P$. exigua, $P$. exigua var. exigua and $P$. exigua var. foveata, are responsible for potato gangrene (Logan \& O'Neill, I970).

\section{METHODS}

Organisms. Six isolates of $H$. solani were obtained from silver scurf lesions that developed during incubation of market potatoes at $\mathrm{I} 2{ }^{\circ} \mathrm{C}$ under humid conditions. One other isolate of this species was from J. Santerre, Agriculture Canada, Ste. Foy, Quebec. One strain of $P$. exigua var. exigua (HPB070673-I) was isolated in this laboratory from a diseased potato by incubation of the lesion on Czapek-Dox agar containing 200 p.p.m. streptomycin. Other strains of $P$. exigua were from C. Logan, Ministry of Agriculture, Belfast, Northern Ireland (two var. exigua, six var. foveata), R. L. Griffith, Rothamsted Experimental Station, Harpenden, Hertfordshire (three var. exigua, three var. foveata), and from C. H. Lawrence (five var. exigua) and W. A. Hodgson (one var. exigua, HPB220873), Agriculture Canada, Fredericton, New Brunswick. In addition, one isolate of Colletotrichum coccodes ('black-dot' organism) from J. Santerre, three isolates of Rhizoctonia solani ('black scurf' organism) from R. L. Griffith, three strains of Alternaria alternata, and one strain of Alternaria tenuissima isolated from potato were examined.

Maintenance and culture. Single spore or single hyphal tip isolates from fungal cultures were maintained on potato carrot agar or malt extract agar. To screen for cytochalasin production, they were grown on $5 \mathrm{ml}$ liquid medium (Rothweiler \& Tamm, 1970) in $30 \mathrm{ml}$ screw-cap vials maintained in a sloping position for 7 days at $25^{\circ} \mathrm{C}$. Cultures were shaken with $\mathrm{Io} \mathrm{ml}$ chloroform, heated at $65^{\circ} \mathrm{C}$ for 5 to Io min, and allowed to stand with the solvent, 
usually for about $15 \mathrm{~min}$ at room temperature. Experiments with $H$. dematioideum (CMI74812) and Phoma strain S298 (from E. Härri, Sandoz A.G., Basel, Switzerland) verified the efficacy of these procedures for production and extraction of cytochalasins A and B. For large scale culture, two strains of $P$. exigua var. exigua (НPB220873 and HPBO70673-I) were grown for 9 days at room temperature in 2.81 Fernbach flasks containing $250 \mathrm{ml}$ medium per flask. Culture medium was extracted directly with chloroform and mycelium was boiled in chloroform, then soaked in the solvent for $3 \mathrm{~h}$.

Thin-layer chromatography. Extracts were concentrated to about $0.5 \mathrm{ml}$ for examination by t.l.c. on $0.25 \mathrm{~mm}$ precoated layers of silica gel DB (Camag). For use as t.l.c. standards, cytochalasins A and B were purchased from I.C.I. Ltd (a sample of the latter was also received from C. Tamm); cytochalasins C and D (Aldridge \& Turner, I969; Minato \& Matsumoto, 1970) were gifts from H. Minato; and cytochalasin E (Aldridge, Burrows \& Turner, I972; Büchi et al. 1973) was from R. C. Shank. Standard solutions of cytochalasins $\mathrm{A}, \mathrm{B}, \mathrm{C}, \mathrm{D}(\mathrm{I} 00 \mu \mathrm{g}$ each $/ \mathrm{ml}$ chloroform) and $\mathrm{E}(200 \mu \mathrm{g} / \mathrm{ml})$ were spotted, together with $5 \mu \mathrm{l}$ extract. Toluene-ethylacetate- $90 \%$ formic acid ( $5: 4: \mathrm{I}$, by vol; TEF) and, for confirmation, chloroform-acetone $(9: \mathrm{I}, \mathrm{v} / \mathrm{v} ; \mathrm{CA})$ and chloroform-methanol $(93: 7, \mathrm{v} / \mathrm{v})$ were used as developing solvent systems. Chromatograms were sprayed with $65 \%(\mathrm{v} / \mathrm{v})$ sulphuric acid then heated at about $100{ }^{\circ} \mathrm{C}$ for 3 to 4 min to allow observation of cytochalasins $\mathrm{A}$ and $\mathrm{B}$ as blue fluorescent spots under reflected and transmitted longwave u.v. light; longer heating at $\mathrm{I} 2 \mathrm{O}^{\circ} \mathrm{C}$ produced a grey to yellow fluorescence. Cytochalasins $C$ and $D$ formed yellow fluorescent spots while cytochalasin E gave a reddish-brown fluorescence and a grey spot in visible light. Approximate estimations of cytochalasin B were made after t.l.c. of rediluted extracts by visual comparison of fluorescence intensities with those of the standard. Cytochalasins A and $\mathrm{B}$ were isolated from concentrated medium extracts of large scale cultures by preparative t.l.c. on $0.5 \mathrm{~mm}$ layers of silicAR $7 \mathrm{GF}$ (Mallinckrodt) by using solvent system CA for development, and crystallized from benzene-hexane and benzene, respectively.

Potato cultures. The cut surfaces of market potatoes, from which a $\mathrm{I} \mathrm{cm}$ layer had been removed, were inoculated with each of two cultures of $P$. exigua var. exigua obtained from single hyphal tips of strain HPB220873 and incubated at $8{ }^{\circ} \mathrm{C}$ on dry towels for three weeks, then on moistened towels for a further three weeks. Rot ( 73 and $94 \mathrm{~g}$ ) was excised and blended with 200 or $250 \mathrm{ml}$ methanol-water $(55: 45, \mathrm{v} / \mathrm{v})$. The mixture was centrifuged at $700 \mathrm{~g}$ for $5 \mathrm{~min}$ and a measured volume of extract shaken with an equal volume of chloroform. Filtration of the chloroform extract through phase-separating filter paper (Whatman PS I) was necessary to clear emulsions, then a portion was evaporated to dryness and analysed by two-dimensional t.l.c. using the solvent systems CA and TEF for first and second developments, respectively. Presumptive cytochalasin B was purified by repeated preparative t.l.c. and confirmed by mass spectroscopic comparison with the standard at a probe temperature of $\mathrm{I} 65$ to $170^{\circ} \mathrm{C}$ (Perkin Elmer RMS-4 instrument operated at $80 \mathrm{eV}$ ).

\section{RESULTS AND DISCUSSION}

Of the species examined, only $P$. exigua var. exigua produced any of the cytochalasins looked for. Our findings support the observation of Bousquet \& Barbier (1972) that this species produces cytochalasin B. Cytochalasins A and B were found in all I 2 strains of this variety, isolated from potatoes in Canada, Northern Ireland and England. Amounts of cytochalasin B produced in the small vial cultures ranged from 40 to $200 \mu \mathrm{g} / \mathrm{ml}$ medium and cytochalasin A was consistently present in small amounts $(<20 \mu \mathrm{g} / \mathrm{ml})$, although up to Ioo $\mu \mathrm{g} / \mathrm{ml}$ was found in the medium from the reference fungus $H$. dematioideum. No cyto- 
chalasins $\mathrm{C}, \mathrm{D}$ or $\mathrm{E}$ were detected in any isolate. Typical $R_{F}$ values for cytochalasins $\mathrm{A}, \mathrm{B}, \mathrm{C}, \mathrm{D}$ and $\mathrm{E}$ were $0.60,0.50,0.38,0.30$ and 0.42 , respectively, in solvent system TEF, and $0.80,0.62,0.26,0.23$ and 0.23 in solvent system CA. Separation of cytochalasins A and B was better in the latter system and also in chloroform-methanol $(93: 7)$, but TEF was best for separation of all five cytochalasins. Minimum detectable amounts on the t.l.c. plate were of the order of $0 . \mathrm{I} \mu \mathrm{g}$. Crystalline cytochalasin A (m.p. I 84 to I $86{ }^{\circ} \mathrm{C}$ and I 88 to $\mathrm{I} 89^{\circ} \mathrm{C}$ ) and cytochalasin $\mathrm{B}$ (m.p. 220 to $22 \mathrm{I}^{\circ} \mathrm{C}, 2 \mathrm{I} 6$ to $2 \mathrm{I} 7{ }^{\circ} \mathrm{C}$ ) were isolated from large scale cultures of two of the strains of $P$. exigua var. exigua. Their identities were confirmed by mixed m.p., and infrared, quantitative u.v., and mass spectroscopic comparisons with authentic cytochalasins $\mathrm{A}$ and $\mathrm{B}$. Thin-layer chromatographic analysis indicated that approximately equal amounts of cytochalasin B were present in the culture medium and mycelium; total estimated yields were $70 \mathrm{mg} / \mathrm{l}$ medium.

It is of particular interest that none of the nine strains of $P$. exigua var. foveata examined formed cytochalasins A or B. This variety has been subdivided on the basis of whether a substance named Antibiotic ' $E$ ' is produced or not (Logan \& O'Neill, 1970) and we screened strains of both types. Phoma exigua var. foveata has been reported to be the main cause of potato gangrene infections in Northern Ireland (Logan \& O'Neill, 1970). In Canada, on the other hand, the pathogen causing phoma rot of potato has usually been termed Phoma tuberosa (synonymous with $P$. exigua var. exigua) (Boerema \& Höweler, I967; Conners, 1967).

Phoma exigua var. exigua was shown to form cytochalasin B on unsterilized potato. Approximate concentrations found were $\mathrm{I}$ and $5 \mu \mathrm{g} / \mathrm{g}$ potato in the excised rot caused by the two cultures of strain HPB220873. The extraction procedure used had previously been found to give $100 \%$ recovery of cytochalasin B added at a concentration of $10 \mu \mathrm{g} / \mathrm{g}$ to sound potato. Two dimensional t.l.c. was necessary to analyse cytochalasin B in the rot at the low concentrations found. Further work will be necessary to determine optimum conditions for production of cytochalasin B in the potato. Poswillo et al. (I973) reported the presence of weak cytochalasin activity (binucleation in cultured $\mathbf{L}$ cells) in extracts from potato concentrates that produced foetal malformations in the marmoset; these potatoes were naturally infected with Phytophthora infestans but other fungi might have been present.

We have demonstrated a direct association between cytochalasin B and one variety of potato gangrene. If further research indicts cytochalasin $\mathrm{B}$ as a teratogen in vivo, then a search for naturally occurring cytochalasin B would be warranted. Recent studies on cytochalasin B fed to pregnant rats in daily doses of $\mathrm{I} \mathrm{mg} / \mathrm{kg}$ body weight have, however, yielded negative results (Ruddick, Harwig \& Scott, 1974).

We thank R. A. Shoemaker, Agriculture Canada, Ottawa for identification of certain strains of $P$. exigua var. exigua and the Alternaria spp., and W. F. Miles for mass spectrometry.

\section{REFERENCES}

Aldridge, D. C., Armstrong, J. J., Speake, R. N. \& Turner, W. B. (I967). The structures of cytochalasins A and B. Journal of the Chemical Society C, 1667-1676.

Aldridge, D. C., Burrows, B. F. \& Turner, W. B. (1972). The structures of the fungal metabolites cytochalasins E and F. Journal of the Chemical Society, Chemical Communications, 148-149.

Aldridge, D. C. \& Turner, W. B. (I969). Structures of cytochalasins C and D. Journal of the Chemical Society C, 923-928.

Boerema, G. H. \& Höweler, L. H. (1967). Phoma exigua Desm. and its varieties. Persoonia 5, i 5-28. 
Bousquet, J. F. \& BARBIER, M. (1972). Sur l'activité phytotoxique de trois souches de Phoma exigua et la présence de la cytochalasine B (ou phomine) dans leur milieu de culture. Phytopathologische Zeitschrift 75, 365-367.

Büchi, G., Kitaura, Y., Yuan, S.-S., Wright, H. E., Clardy, J., Demain, A. L., Glinsukon, T., Hunt, N. \& Wogan, G. N. (1973). Structure of cytochalasin E, a toxic metabolite of Aspergillus clavatus. Journal of the American Chemical Society 95, 5423-5425.

CARTER, S. B. (1972). The cytochalasins as research tools in cytology. Endeavour 31, 77-82.

Conners, I. L. (1967). An Annotated Index of Plant Diseases in Canada, Publication No. 1251, p. 270. Ottawa: Canada Department of Agriculture.

Linville, G. P. \& Shepard, T. H. (1972). Neural tube closure defects caused by cytochalasin B. Nature New Biology 236, 246-247.

Logan, C. \& O’NeILl, R. (1970). Production of an antibiotic by Phoma exigua. Transactions of the British Mycological Society 55, 67-75.

Minato, H. \& Matsumoto, M. (1970). Studies on the metabolites of Zygosporium masonii. I. Structure of zygosporin A. Journal of the Chemical Society C, 38-45.

Poswillo, D. E., Sopher, D., Mitchell, S. J., Coxon, D. T., Curtis, R. F. \& Price, K. R. (I973). Investigations into the teratogenic potential of imperfect potatoes. Teratology 8, 339-348.

RENWICK, J. H. (I972). Hypothesis: anencephaly and spina bifida are usually preventable by avoidance of a specific but unidentified substance present in certain potato tubers. British Journal of Preventive and Social Medicine 26, 67-88.

RENWICK, J. H. (1973). Prevention of anencephaly and spina bifida in man. Teratology 8, 32 I-324.

RothweIler, W. \& TAMM, C. (1970). Isolierung und Struktur der Antibiotica Phomin und 5-Dehydrophomin. Helvetica chimica acta 53, 696-724.

Ruddick, J. A., Harwig, J. \& ScotT, P. M. (1974). Nonteratogenicity in rats of blighted potatoes and compounds contained in them. Teratology 9, I65-I68.

ShePARD, T. H. (1973). Anencephaly and potatoes. Lancet i, 97. 